\title{
Profile Characteristics of Televiewing Farmers of Andhra Pradesh, India
}

\author{
M. Venkata Krishnaji ${ }^{1 *}$ and T. Gopikrishna ${ }^{2}$ \\ ${ }^{1}$ Department of Agricultural Extension, Agricultural College, \\ Bapatla - 522101, Andhra Pradesh, India \\ ${ }^{2}$ Department of Agricultural Extension, O/o Director of Extension, \\ Lam, Guntur - 522 034, Andhra Pradesh, India \\ *Corresponding author
}

\section{A B S T R A C T}

\begin{tabular}{|l|}
\hline Keyw or d s \\
$\begin{array}{l}\text { Profile } \\
\text { characteristics, } \\
\text { Televiewing } \\
\text { farmers }\end{array}$ \\
\hline Article Info \\
\hline $\begin{array}{l}\text { Accepted: } \\
\text { 17 September } 2019 \\
\text { Available Online: } \\
\text { 10 October 2019 }\end{array}$ \\
\hline
\end{tabular}

\section{Introduction}

Communication is key factor for social development and social change. Mass media are used as channels of mass communication. Usage of mass media is the quickest way of bringing change in the 'mind set' of traditional society (Lerner, 1958). The main aim or function of mass media is to inform, educate and motivate the people to accept new ideas and technologies so as to increase their living conditions and status. Television provides excellent learning opportunity to rural population. The original or true India lives in villages only. Nearly 80.00 percent of its population lives in villages and villagers main profession is farming. Farmers are the back bone of Indian economy and so agriculture is 
the main source of income for rural people and 50 per cent of national income comes from them. The livelihood of three fourth population is provided by agriculture. This means the rural population will be curious and anxious to watch television if farm based programmes are being telecasted. As television is the mirror of society, it is sure to benefit farmers and so farm-based programmes should be telecasted.

The present investigation was undertaken to measure the profile characteristics televiewing farmers of Andhra Pradesh from 2014 - 2019.

\section{Materials and Methods}

The study was conducted by using ex-post facto research design. The state, Andhra Pradesh was selected purposively as the researcher belonged to this state and well acquainted with the regional language i.e., Telugu which would help to build a good rapport and also facilitates for in depth study through personal observation and interview. Four districts out of 13 districts namely West Godavari, Kurnool, Guntur and Srikakulam were selected randomly.

After listing all the mandals of selected districts, two mandals from each selected district were chosen randomly for the purpose of present study. A total number of eight mandals namely Yelamanchili, Mogalthuru (West Godavari) Amadalavalasa, Etcherla (Srikakulam) Maddikera, C.Belagal (Kurnool), Tsunduru, Duggirala (Guntur), were selected randomly.

After listing out the total number of farmers who are in possession of TV sets, 15 farmers from each of the selected village was chosen by simple random sampling method, there by the total sample size become 240 . The primary data were collected using a pre-tested structured interview schedule by conducting personal interview. Data was tabulated, classifieds and analysed using frequency percentage (Table 1).

\section{Results and Discussion}

In social science research, it was essential to know about respondent's profile which would serve as a basis for clear and thorough understanding about the subject being studied. A bird's eye view of the Table 2, depicted that distribution of the televiewing farmers in accordance with selected profile characteristics viz., age, education, farm size, farming experience, socio-economic status, innovativeness, mass media exposure, marketing orientation, risk orientation, economic orientation, scientific orientation, extension contact, annual income, social participation, cropping intensity and training exposure.

It could be inferred from the Table 2, that 44.58 per cent of telviewing farmers belonged to middle age, followed by the rest belonging to old age (34.17\%) and young age (21.25\%). The reason might be that, the middle and old aged people depends more on television for getting agricultural information. They may not have proper awareness about new ICTs like YouTube, Face Book and Portals etc.

It can be observed that 22.08 per cent of the televiewing farmers belonged to primary school category, followed by those belonging to functionally literate $(17.92 \%)$, illiterate (15.83\%), middle school (14.17\%), high school (14.17\%), intermediate education $(10.00 \%)$ and graduation and above $(5.83 \%)$ categories. The reason might be that more than half of the respondents were under primary school education, functionally literate and illiterate categories.

Almost more than one fourth $(26.7 \%)$ of the televiewing farmers belong to marginal 
followed by those belonged to small farmers (22.08\%), landless (18.03\%), semi-medium $(17.92 \%)$, medium $(10.83 \%)$ and large $(4.17 \%)$ farmers categories. This might be due to the fragmentation of land holdings because of separation of joint families.

It was observed that more than half $(50.84 \%)$ of the televiewing farmers had high level of farming experience, followed by the rest with medium (32.08\%) and low (17.08\%) level of farming experience. This might be due to the majority of the telviewing farmers belonging to middle and old age. Therefore, their experience in farming may be reason for increased viewership of farm broadcast programmes. This finding was in line with the findings of Thiranjangowda (2005).

An overview of Table 2, illustrated that more than half $(54.17 \%)$ of the televiewing farmers had medium level of socio-economic status, followed by those had low $(28.75 \%)$ and high $(17.08 \%)$ levels of socio-economic status and it can be understood that 40.42 per cent of the televiewing farmers had medium level of innovativeness, followed by rest with low $(35.00 \%)$ and high (24.58\%) levels of innovativeness. This might be due to the majority of the televiewing farmers being middle and old aged with low education, small to marginal land holdings, medium to low mass media exposure and medium to low risk taking ability. This finding was in concurrence with the findings of Tidke et al., (2012)

The data from the table clearly indicated that majority $(52.92 \%)$ of the televiewing farmers had medium mass media exposure, followed by 27.08 per cent with low and 20.00 per cent with high mass media exposure. The reason for medium to low mass media exposure is due to low level of education, lack of awareness of farmers regarding the broadcasting timings except some popular programmes like Annadata and Pasidi Pantalu, Broadcasting of routine information in some channels, formal way of presenting programmes, parallel transfer of technology through input dealers and private companies representatives.

The findings that were presented in Table 2, explained that two-fifths $(39.17 \%)$ of the televiewing farmers had medium marketing orientation, followed by remaining with low $(35.83 \%)$ and high $(25.00 \%)$ levels of marketing orientation. The plausible reasons might be lack of awareness about scientific processing and grading, non - availability of storage structures and lack of information about market intelligence. These findings were somewhat contrast to the findings of Prabhugouda (2011), Mehta and Madhuri (2012).

An over view of the above table explained that less than half (44.17\%) of the televiewing farmers had medium level of risk orientation, followed by those with low (31.67\%) and high $(24.16 \%)$ levels of risk orientation. This might be due to majority of the televiewig farmers belonging to middle to old age, small to marginal farmers with low to medium annual income, medium to low socio-economic status, innovativeness and medium to low scientific orientation, hence they were reluctant to take calculated risks in adopting new technologies. Similar findings were reported by Gowda et al., (2011).

It could be inferred from Table 2, that more than half $(55.42 \%)$ of the televiewing farmers had medium economic orientation, followed by those with low (24.16\%) and high $(20.42 \%)$ levels of economic orientation. Overall, 80.00 per cent of televiewing farmers had low to medium economic orientation. It also seen that majority of the televiewing farmers $(55.83 \%)$ had medium scientific orientation, followed by those with low (24.17\%) and high (20.00\%) levels of scientific orientation. This trend might be due to lack of faith on scientific technologies like 
fertilizer management, sowing times and seed rate etc. It need to be rectified through proper assessment of technologies through frontline extension system before entering into second line extension. The above findings were in conformity with the findings of Nrusimha Kalyan et al., (2012) and Tidke et al., (2012).

An overview of the above Table 2, indicated that three-fifths $(60.84 \%)$ of the televiewing farmers had medium extension contact, followed by those with low (22.08\%) extension contact. The probable reasons were: lack of awareness among farmers about organizational hierarchy. Extension contact may be improved with proper awareness about organizational hierarchy, utilization of extension functionaries only for technical work. The above findings were in agreement with the findings of Sandesh (2004)

Table.1 Selected profile characteristics and their empirical measurement used for the study

\begin{tabular}{|c|c|c|}
\hline S. No. & Profile characteristics & Empirical Measurement \\
\hline 1. & Age & Chronological age of respondents was considered \\
\hline 2. & Education & $\begin{array}{l}\text { Scale developed by Venkataramaiah (1983) with suitable } \\
\text { modifications was used }\end{array}$ \\
\hline 3. & Farm Size & $\begin{array}{l}\text { Interval scaling procedure was adopted as per the AP Land } \\
\text { Ceiling Act }\end{array}$ \\
\hline 4. & Farming Experience & Interval scaling procedure was adopted \\
\hline 5. & Socio-Economic Status & $\begin{array}{l}\text { Scale developed by Venkataramaiah (1983) with suitable } \\
\text { modifications was used }\end{array}$ \\
\hline 6. & Innovativeness & $\begin{array}{c}\text { Scale developed by Rao (1985) with suitable modifications was } \\
\text { used }\end{array}$ \\
\hline 7. & Mass Media Exposure & $\begin{array}{c}\text { Scale developed by Seshachar (1980) with suitable } \\
\text { modifications was used }\end{array}$ \\
\hline 8. & Marketing Orientation & $\begin{array}{c}\text { Schedule developed by Samantha (1977) with required } \\
\text { modifications was used }\end{array}$ \\
\hline 9. & Risk Orientation & $\begin{array}{c}\text { Scale developed by Supe (1969) with suitable modifications } \\
\text { was used }\end{array}$ \\
\hline 10. & Economic Orientation & $\begin{array}{l}\text { Scale developed by Supe (1969) with suitable modifications } \\
\text { was used }\end{array}$ \\
\hline 11. & Scientific Orientation & $\begin{array}{l}\text { Scale developed by Supe (1969) with suitable modifications } \\
\text { was used }\end{array}$ \\
\hline 12. & Extension Contact & $\begin{array}{c}\text { Scale developed by Ponnappan (1982) with suitable } \\
\text { modifications was used }\end{array}$ \\
\hline 13. & Annual Income & $\begin{array}{l}\text { Scale developed by Ramamurthy (1983) with suitable } \\
\text { modifications was used }\end{array}$ \\
\hline 14. & Social Participation & $\begin{array}{l}\text { Scale developed by Trivedi (1963) with suitable modifications } \\
\text { was used }\end{array}$ \\
\hline 15. & Cropping Intensity & Index was developed for the study \\
\hline 16. & Training Exposure & Interval scale was developed for the study \\
\hline
\end{tabular}


Table.2 Selected profile characteristics of Televiewing farmers

\begin{tabular}{|c|c|c|c|c|}
\hline \multirow[t]{2}{*}{ S. No. } & \multirow[t]{2}{*}{ Independent variables } & \multirow[t]{2}{*}{ Category } & \multicolumn{2}{|c|}{ Respondent } \\
\hline & & & $\mathbf{F}$ & $\mathbf{P}$ \\
\hline 1. & Age & $\begin{array}{ll}\text { Young age } & (<35 \text { years }) \\
\text { Middle age } & (36 \text { to } 59 \text { years }) \\
\text { Old age } & (>60 \text { years })\end{array}$ & $\begin{array}{c}51 \\
107 \\
82\end{array}$ & $\begin{array}{l}21.25 \\
44.58 \\
34.17\end{array}$ \\
\hline 2. & Education & $\begin{array}{l}\text { Illiterate } \\
\text { Functionally literate } \\
\text { Primary school } \\
\text { Middle school } \\
\text { High school } \\
\text { Intermediate Education } \\
\text { Graduation and above }\end{array}$ & $\begin{array}{l}38 \\
43 \\
53 \\
34 \\
34 \\
24 \\
14\end{array}$ & $\begin{array}{l}15.83 \\
17.92 \\
22.08 \\
14.17 \\
14.17 \\
10.00 \\
5.83\end{array}$ \\
\hline 3. & Farm Size & $\begin{array}{l}\text { Landless } \\
\text { Marginal (Less than } 2.5 \text { acres) } \\
\text { Small ( } 2.5 \text { to } 5 \text { acres }) \\
\text { Semi medium ( } 5 \text { to } 10 \text { acres) } \\
\text { Medium ( } 10 \text { to } 25 \text { acres) } \\
\text { Large (More than } 25 \text { acres }\end{array}$ & $\begin{array}{l}44 \\
64 \\
53 \\
43 \\
26 \\
10\end{array}$ & $\begin{array}{l}18.30 \\
26.70 \\
22.08 \\
17.92 \\
10.83 \\
04.17\end{array}$ \\
\hline 4. & $\begin{array}{c}\text { Farming Experience } \\
\bar{X} \quad=3.02 \\
\text { S.D }=1.61\end{array}$ & $\begin{array}{l}\text { Low }(<1.41) \\
\text { Medium }(1.41 \text { to } 4.62) \\
\text { High }(>4.62\end{array}$ & $\begin{array}{c}41 \\
77 \\
122\end{array}$ & $\begin{array}{l}17.08 \\
32.08 \\
50.84\end{array}$ \\
\hline 5. & $\begin{array}{c}\text { Socio-Economic Status } \\
\bar{X}=17.92 \\
\text { S.D }=9.42\end{array}$ & $\begin{array}{l}\text { Low }(<8.50) \\
\text { Medium }(8.50 \text { to } 27.33) \\
\text { High }(>27.33)\end{array}$ & $\begin{array}{c}69 \\
130 \\
41\end{array}$ & $\begin{array}{l}28.75 \\
54.17 \\
17.08\end{array}$ \\
\hline 6. & $\begin{array}{l}\text { Innovativeness } \\
\bar{X}=18.04 \\
\text { S.D }=2.35\end{array}$ & $\begin{array}{l}\text { Low }(<15.70) \\
\text { Medium }(15.70 \text { to } 20.39) \\
\text { High }(>20.39)\end{array}$ & $\begin{array}{l}84 \\
97 \\
59\end{array}$ & $\begin{array}{l}35.00 \\
40.42 \\
24.58\end{array}$ \\
\hline 7. & $\begin{array}{c}\text { Mass Media Exposure } \\
\bar{X}=14.01 \\
\text { S.D }=3.92\end{array}$ & $\begin{array}{l}\text { Low }(<10.09) \\
\text { Medium }(10.09 \text { to } 17.93) \\
\text { High }(>17.93)\end{array}$ & $\begin{array}{c}65 \\
127 \\
48\end{array}$ & $\begin{array}{l}27.08 \\
52.92 \\
20.00\end{array}$ \\
\hline 8. & $\begin{array}{c}\text { Marketing Orientation } \\
\bar{X}=12.08 \\
\text { S.D }=1.17\end{array}$ & $\begin{array}{l}\text { Low }(<10.91) \\
\text { Medium }(10.91 \text { to } 13.26) \\
\text { High }(>13.26)\end{array}$ & $\begin{array}{l}86 \\
94 \\
60\end{array}$ & $\begin{array}{l}35.83 \\
39.17 \\
25.00\end{array}$ \\
\hline 9. & $\begin{array}{l}\text { Risk Orientation } \\
\bar{X}=11.57 \\
\text { S.D }=1.70\end{array}$ & $\begin{array}{l}\text { Low }(<9.87) \\
\text { Medium }(9.87 \text { to } 13.26) \\
\text { High }(>13.26)\end{array}$ & $\begin{array}{c}76 \\
106 \\
58\end{array}$ & $\begin{array}{l}31.67 \\
44.17 \\
24.16\end{array}$ \\
\hline 10. & $\begin{array}{c}\text { Economic Orientation } \\
\bar{X}=18.44 \\
\text { S.D }=7.02\end{array}$ & $\begin{array}{l}\text { Low }(<11.42) \\
\text { Medium }(11.42 \text { to } 25.46) \\
\text { High }(>25.46)\end{array}$ & $\begin{array}{c}58 \\
133 \\
49\end{array}$ & $\begin{array}{l}24.16 \\
55.42 \\
20.42\end{array}$ \\
\hline 11. & $\begin{array}{l}\text { Scientific Orientation } \\
\bar{X}=17.70\end{array}$ & $\begin{array}{l}\text { Low }(<10.65) \\
\text { Medium }(10.65 \text { to } 24.75)\end{array}$ & $\begin{array}{c}58 \\
134\end{array}$ & $\begin{array}{l}24.17 \\
55.83\end{array}$ \\
\hline
\end{tabular}




\begin{tabular}{|c||l|l|c|c|}
\hline & S.D $=7.05$ & High $(>24.75)$ & 48 & 20.00 \\
\hline 12. & Extension Contact & Low $(<5.16)$ & 53 & 22.08 \\
& $\bar{X}=8.70$ & Medium 5.16 to 12.24) & 146 & 60.84 \\
& S.D $=3.54$ & High $(>12.24)$ & 41 & 17.08 \\
\hline 13. & Annual Income & Low $(<2.44)$ & 94 & 39.16 \\
& $\bar{X}=4.02$ & Medium $(2.44$ to 5.60$)$ & 79 & 32.92 \\
& S.D $=1.56$ & High $(>5.60)$ & 67 & 27.92 \\
\hline 14. & Social Participation & Low $(<1.17)$ & 82 & 34.16 \\
& $\bar{X}=2.48$ & Medium $(1.17$ to 3.94$)$ & 115 & 47.92 \\
& S.D $=1.46$ & High $(>3.94)$ & 43 & 17.92 \\
\hline $\mathbf{1 5 .}$ & Cropping Intensity & Low $(<82.15)$ & 71 & 29.58 \\
& $\bar{X}=124.03$ & Medium $(82.15$ to 165.91$)$ & 138 & 57.50 \\
& S.D $=41.88$ & High $(>165.91)$ & 31 & 12.92 \\
\hline 16. & Training Exposure & Low $(<1.05)$ & 77 & 32.08 \\
& $\bar{X}=2.36$ & Medium $(1.05$ to 3.67$)$ & 110 & 45.84 \\
& S.D $=1.31$ & High $(>3.67)$ & 53 & 22.08 \\
\hline
\end{tabular}

An over view of the Table 2, indicated that almost two-fifths $(39.17 \%)$ of the televiewing farmers had low level of annual income, followed by the rest with medium $(32.92 \%)$ and high $(27.91 \%)$ levels of annual income. This might be due to the low yields and high cost of cultivation, frequent crop failures due to floods and cyclones in coastal areas and drought situation in rain fed areas. These findings were in line with the findings of Kumar et al., (2013) and Muhammad and Mondol (2015).

From the Table 2, it could be concluded that less than half $(47.92 \%)$ of the televiewing farmers had medium level of social participation, followed by 34.17 per cent of them with low level and 17.91 per cent of them with high level of social participation. The trend of medium to low level of social participation was due to, majority of televiewing farmers being the members in one to two key social organizations viz. primary agricultural cooperative societies, water users associations and grampanchayaths etc., The above findings were in agreement with the findings of Gowda et al., (2011).
The Table 2, shown that majority $(57.50 \%)$ of televiewing farmers fall under medium cropping intensity category followed by low $(29.58 \%)$ and medium $(12.92 \%)$ levels of cropping intensity. The trend of medium to low level of cropping intensity because of the farmers not utilizing entire land due to the limited availability of water and majority of the farmers depending on rain fall and borewells for cultivating their crops. In contrast to this, farmers having canal irrigation sources for kharif and rabi utilizing its fullest potential for entire land area.

An over view of the Table 2, indicated that more than two-fifths (45.84\%) of the televiewing farmers had medium level of training exposure, followed by the rest with low $(32.08 \%)$ and high $(22.08 \%)$ levels of training exposure. This might be due to the lack of awareness about regular trainings conducted by ground level extension functionaries, time of training programmes coinciding with their field work, lack of newness and lack of need based programmes. It is observed from the study that majority of the televiewing farmers were middle and old 
aged, this might be due to majority of youth not interested in agriculture and they were choosing other professions. Hence, the government need to formulate some special programmes like "Attracting Rural Youth in Agriculture" to attract youth into agriculture. Majority of the televiewing farmers are educated up to primary school level only. Education is the key for overall development of the farmers and they can easily understand the scientific technology and also realise the need and importance of change in farming practices.

Hence, the government needs to formulate policies for making the education is compulsory (up to $10^{\text {th }}$ standard) for all the children. Most of the televiewing farmers had medium level of innovativeness and mass media exposure. Innovativeness is the key factor for testing any new technology in farmers fields, hence to increase the innovativeness among farmers, the farm broadcasts need to include more of success stories along with economic returns, as the motivation play a key role in increasing the innovativeness of the individuals. At the same time, mass media exposure of farmers can be increased by conducting more awareness programmes about various mass media channels available for agriculture and rural development and also broadcasting more factual/ practical information in an interesting and motivational way. Majority of the televiewing farmers had medium level of marketing orientation and risk orientation. Marketing orientation helps in getting high economic returns for their farm produce. To improve the marketing orientation of farmers, government must increase the scale of finance, provide information about market trend well in advance and conduct awareness and skill oriented trainings on processing, grading and value addition technologies. At the same time, farmers risk orientation ability can be improved by broadcasting more number of success stories, farmers experience and case studies through mass media channels to reduce fear among farming community. Majority of the televiewing farmers had medium level of economic orientation and scientific orientation. The economic orientation will be improved by teaching better utilization of inputs and use of low-cost technologies among farmers. At the same time, scientific orientation is an important factor for adoption of proven technologies in farmers fields. Hence, it needs to organize more number of frontline demonstrations and cluster frontline demonstrations for gaining confidence of the farmers about scientific technology. In addition to this, proper publicity in the form of case studies, success stories should be broadcasted through mass media for creating awareness among farmers. Majority of the televiewing farmers had medium extension contact and low annual income. Extension contact of farmers can be improved by increasing the technical knowledge and skills of the grass root level and middle level extension staff. Extension staff must be utilized for advisory service rather assigning other duties. At the same time, the annual income of farmers will be improved by accelerating the adoption of integrated farming systems approach, climate resilient agriculture, drought mitigate technologies to avoid crop loss. Extension system need to be revamped towards market led extension, to make the farmer as agriprenuer rather mere producer. Majority of the televiewing farmers had medium cropping intensity and training exposure. The cropping intensity of farmers can be improved by popularizing the double cropping system in drought areas, effective utilization of irrigation water and promotion of summer pulse as third crop in canal irrigated situations. Training exposure will be improved by conducting limited number of need based trainings instead of target oriented large number of trainings. 


\section{References}

Gowda, A. T., Babu, Ramesh. Ch., Naidu, G. B. M. R and Srinivasa Rao, V. 2011. Profile characteristics of sugarcane growers in Mandhya district of Karnataka. The Andhra Agricultural Journal. 58 (2): 123-126.

Kumar, P. Ganesh., Jyosthna, M. K and Reddy, Lakshmi. P. 2013. Knowledge and extent of adoption of improved practices of Chickpea through KVK interventions. Journal of Research, ANGRAU. 41 (3): 58-63

Muhammad, Noor and Mondol, Md. Abu S. 2015. Effectiveness of union information and service center in utilization of farm information. International Journal of Agricultural Extension. 3 (1): 37-45.

Sandesh, H. M. 2004. A profile study of Kannada farm magazine readers in Karnataka. M. Sc. (Ag.) Thesis, University of Agricultural Sciences, Dharwad, Karnataka, India.

Kalyan, V. Nrusimha, Satya Gopal, P and Prasad, S.V. 2012. Profile characteristics of groundnut farmers in Chittoor district of Andhra Pradesh. The Andhra Agricultural Journal. 59 (2): 332-335.

Tidke, G. R., Rathod, M. K and Mandve, R. P. 2012. Knowledge and adoption of farmers about the management of pod borer complex in pigeon pea. International Journal of Extension Education. 8 (1): 71-76.

Prabhugouda, K. 2011. Entrepreneurial behaviour of pomegranate growers in Koppal district of Karnataka. M. Sc. (Ag.) Thesis. Acharya N. G. Ranga Agricultural University, Rajendranagar, Hyderabad, India.

Mehta, B. M and Madhuri, S. 2012. Entrepreneurial behaviour of mango growers of Valid district of Gujarat state. Indian Research Journal of Extension Education. 12 (1): 78-82.

Thiranjangowda, B. T. 2005. A study on cultivation and marketing pattern of selected cut flowers in Belgaum district of Karnataka. M. Sc. (Ag.) Thesis. University of Agricultural Sciences, Dharwad, Karnataka, India.

\section{How to cite this article:}

Venkata Krishnaji, M. and Gopikrishna, T. 2019. Profile Characteristics of Televiewing Farmers of Andhra Pradesh. Int.J.Curr.Microbiol.App.Sci. 8(10): 2452-2459.

doi: https://doi.org/10.20546/ijcmas.2019.810.285 